\title{
Perceived Godfatherism, Political Awareness and Voting Behaviours in Nigeria: A Clarion Call to All Prospective Electorates.
}

\author{
Abiodun Musbau LAWAL \\ Department of Psychology, Faculty of Humanities and Social Sciences, \\ Federal University Oye-Ekiti, Ekiti state, Nigeria. \\ Adebayo Ibrahim ADELEKE \\ Department of General Studies \\ Moshood Abiola Polytechnic, Abeokuta, Ogun state, Nigeria
}

\begin{abstract}
Poor leadership in Nigeria is making her citizens to lose interest in the electoral system and governance in the country. The study examined ethnicity, religion, perceived godfatherism and political awareness as predictors of voting behaviour among electorates in Nigeria. This was a survey research where ex-post facto research design was adopted. Data were collected via structured questionnaires; and 473 participants were sampled using accidental sampling selection method. Hypotheses stated in the study were tested using multiple regression and t-test for independent samples. Results revealed that all the predictor variables jointly predicted electorates' voting behaviour. However, perceived godfatherism and political awareness independently contributed in explaining voting behaviour of electorates. Male electorates were not significantly different in voting behaviour from female electorates. It is concluded that electorates in Nigeria see the presence of godfatherism and being informed about the political processes as relevant to exercising their civic rights. It is recommended that issue of godfatherism should be abated and political awareness should be intensified to ensure higher voting behaviour in Nigeria.
\end{abstract}

Keywords: Voting behaviour, godfatherism, political awareness, electorates, Nigeria.

\section{INTRODUCTION}

There is no doubt that all is not well with political system and governance in Nigeria. This may have to do with improper ambition of some of the political leaders to hold on to power indefinitely and not considering what the constitution says or feelings of Nigerian people on the subject-matter. Levels at which electorates in Nigeria perform their civic rights by casting their votes to elect their representatives seem to be reduced these days. People do not come out today in great number to cast their votes as they used to do in the past elections. This may be connected to lack of trust in the Nigerian electoral system or election results. Previous study regarding voting behaviour of electorates in Nigeria had found that age and self-esteem independently predict voting behaviour among Nigerian electorates (Balogun \& Olapegba, 2007). Perhaps, considering a number of other relevant factors that could be responsible for poor voting behaviour of electorates might be of paramount at this era; especially in Oyo state; being one of the states in Nigeria that is believed to be known for godfatherism in her electoral processes.

Voting is simply when a group of people makes a decision on a subject that concerns them as a whole. In many countries across the globe, people vote to choose their leaders and to decide 
public issues. Voting thus, is a means of aggregating individual preferences into collective decision in an election; the action of formally indicating one's choice of candidate or political party at an election. With this in mind, voting is seen as a form of behaviour that an individual exhibits to exercise his or her civic right. However, voting behaviours among electorates could have some motivating and determining factors in the Nigeria context. Some of the notable likely factors that may predict voting behaviours of electorates in Nigeria include ethnicity, religion, perceived godfatherism and political awareness.

Godfatherism is greatly perceived to have effect on voting behaviours among Nigerian electorates. The issue of Godfatherism is rampant almost everywhere in the Nigeria political processes irrespective of the tribe. Going by the history, Godfatherism became popular in Nigerian political space in the 1960's, when early post-independence leaders became godfathers (Mamah, 2007). However, the handiwork of godfathers was visible at the return to civil rule in 1979, but military regimes that characterized the 1980's obstructed its activities. The 1999 civil rule ushered in another form of godfatherism, which reached its climax during the wanton destruction of lives and properties that witnessed the violent confrontation between a godfather (Chris Uba) and the then governor of Anambra state, Nigeria (Chris Ngige). This act alone; perhaps, brings to the fore, a new dimension to the practice of godfatherism in Nigeria. In Ibadan, Oyo state, Nigeria, late Lamidi Adedibu used to be identified as the main godfather in the state politics; and this used to go a long way with electoral system of the state until his death in the year 2009. All these are in contrast to the roles played by the then godfathers in Nigeria's democratic practice between 1958 and 1983. Therefore, Godfathers can be viewed as brokers, go-betweens for politicians seeking political power in a situation of voters' alienation and distrust in return for contracts and political appointments.

Regarding perceived godfatherism and voting behaviour among electorates, Adeoye (2009) explored the relationship between godfathers and godsons with a particular attention to its influence on the development of Nigeria's politics, and seeming demise of resourceful governance in the country. Adeoye (2009) found that there was a shift in the modus operandi of post-independence godfatherism, and what obtains in contemporary Nigeria was violenceinspired godfatherism, which successfully replaced politics of welfare by politics of warfare in the affected areas. In a similar vein, Abdul-jelili (2009) identified godfatherism; a form of patron-client relationship as a social-political problematic which has resulted in political insecurity and violence; threatening participatory democracy, peace, political security and the consolidation of democracy since the fourth-republic started on the 29th of May, 1999. In another perspective, Olarinmoye (2008) focused on the realities of existence of godfathers, political parties and voters in Nigeria; and argued that electoral corruption is the result not just of the avariciousness of godfathers and politicians. Also, that electoral corruption is further entrenched by the political and social existential demands of the godfather, which could only be met by further exercises in electoral corruption, though this time in favour of the godfathers themselves. From the aforementioned studies, it can be deduced that godfatherism in politics is inevitable, but there is the need for proper management of godfather or godson relationship in Nigeria. Apart from perception of godfatherism, extent of political awareness in electorates may be relevant in determining their voting behaviour.

It is generally recognized that individual voters differ greatly in their ability and incentives to gather and understand political information; and that this affects opinion formation processes (Converse, 2000). Moreover, the opportunity for political learning also depends on the type of information available in the political environment. It is suggested that the campaign context 
interacts with individual level characteristics in influencing the vote, since intensive referendum campaigns provide a favourable informational environment that encourages citizens to absorb and process more information and consequently rely on more sophisticated decision criteria. How informed or aware an electorate is, about the political issues in his or her surrounding may determine whether he or she will go out to cast vote or not. Of course, if you are not aware of the politics in your community you might not be willing to exercise your civic rights. Examining political awareness and voting behaviour, Oluwatula and Arogundade (2008) investigated the relationships between psychological and political awareness; and desire for political power among university students in Nigeria. In their study, some strong relationships were found between levels of psychological and political awareness and need for personal power and need for institutional power among the participants. In another study, Hobolt (2005) investigated how political information influences voting behaviour; and argued that political information conditions the way in which people make decisions in referendums by altering the impact of the decision criteria that voters use. It is argued that people with high levels of political awareness receive more information, and consequently rely more on their own attitudes and less on elite cues when deciding. Apart from perceived godfatherism and political awareness, demographic factors such as ethnicity and religion may help in predicting voting behaviours of electorates in Nigeria.

Conventional wisdom appears to hold that ethnicity provides a major social cleavage for voting behaviour and party affiliation in Africa. In some cases, ethnicity matters for voter alignment, but even in these cases it is only one factor among others that can explain voting behaviour. Overall, ethnicity matters to very different degrees in different countries and even so for the different parties within the same country. Ethnicity in this context includes whether an electorate is a Yoruba, Hausa, Igbo or any other ethnics in Nigeria. Literature review indicates that Oluwatula and Arogundade (2009) examined the influence of some psychosocial variables such as ethnic and religious affiliation, self-esteem, personality, family background, age, political party ideology, gender, perceived benefit and personal attributes of the candidate, on voting behaviour of Nigerians; they . Similarly, Balogun and Olapegba (2007) examined the influence of psychological and demographic variables (age, ethnicity, sex, social class, media and self-esteem) on voting behaviour within Ibadan metropolis and reported no independent contribution of ethnicity in explaining voting behaviour.

Religion is another demographic factor that is likely to predict voting behaviours of electorates in Nigeria. Religion includes religious affiliations such as Christianity, Islam, traditional religion and other unclassified religious affiliation. Forster (2008) is one of the many studies that have examined the influence of religion on the voting behaviour of citizens; thus, making religion one of the most important factors in determining voting behaviour. Overwhelming amounts of literature have been devoted to the importance of religion in regards to voting behaviour. Forster (2008) used data from the National Election Study to examine the impact, or lack thereof, of religious preferences in the last four U.S. presidential elections. Using multinomial logistic regression, the paper looked for the influence of religion, in terms of specific preferences as well as attendance, on presidential vote choice as well as stated preferences on individual issues as diverse as abortion rights, same-sex marriage, environmental preservation, foreign intervention, and social welfare spending. Additionally, the paper explored interactions between religious preferences and demographic characteristics such as race, gender, and age. The paper concluded by suggesting that the increased importance of foreign policy in presidential elections has resulted in a decline in the influence of religion and religiously-based social preferences on voting behaviour at the national level. Fastnow, Grant, and Rudolph (1999) investigated the effect of religion in the House of Representatives to see how religion 
affected vote choice. It was found that "members' votes represent both their [the representatives'] own religious affiliation, and the religious groups within their districts". In another study, Fox and Richardson (2001) found "that the only variable that consistently allowed prediction of voting behaviour is religious affiliation." When other variables were included in this study, there was little significance in voting behaviour (Fox \& Richardson, 2001). Fox and Richardson (2001) concluded that "religious affiliation is always the best predictor, even though in some cases its effect is small. From the aforementioned findings, religion has a profound influence on the party affiliation and voting tendency of individuals, though change has been occurring slightly over time.

Studies of the gender gap in electoral behaviour have now become a familiar feature of social science research. Yet, there is still disagreement about its nature and extent; as well as what accounts for its development. Gender in this context involves whether the electorates are male or female; examining how this might influence their voting behaviours. Looking at gender difference in voting behaviour, Gill (2003) analyzed voter choice in selected House of Representatives elections during the past 30 years. He argued that no gender gap exists in the votes garnered by the main parties because, first, influential people are not simply able to 'deliver' votes from their networks - most accounts of voter choice fail to discuss gender, an oversight considering that most networks are gender-based - and, second, 'women's issues' have no special relevance to women in their vote choice. Instead, women and men vote for the Liberal Democratic Party because they associate the Party with stability and increased standards of living, including substantial social provisions. In another study, Sanbonmatsu (2002) looked at the different stereotypes associated with men and women regarding "candidate beliefs, issue competency, and traits, and voter gender." In regards to gender stereotypes Sanbonmatsu claimed that the general population tends to view women as more capable to understand issues dealing with women's rights, whereas men are more capable to deal with issues such as foreign policy and defense. Sanbonmatsu reported that their gender stereotypes influence a preference for certain genders in office. Sanbonmatsu (2002) found that in regards to issues that voters "who think women are more likely to take their position on abortion - a stereotypically female strength - are more likely to prefer the female candidate." The voters, especially female voters, who are pro-choice and support women's rights believe that a female representative will be more likely to vote pro-choice than a male representative. The purpose of this study was to examine if ethnicity, religion, perceived godfatherism and political awareness would independently and jointly predict voting behaviours among electorates in Oyo state, Nigeria.

\section{Research Design}

\section{METHOD}

The study was a survey using ex-post facto research design to investigate how ethnicity, religion, godfatherism and political awareness independently and jointly predict voting behaviour among electorates.

\section{Participants}

Four hundred and seventy three (473) electorates who came from several local government areas in Oyo state was sampled in the study using accidental sampling technique. The electorates included 247 (52.2\%) males and 226(47.8\%) females.

\section{Table 1: Socio-demographic Characteristics of Participants}




\begin{tabular}{|c|c|c|}
\hline Variable & No & $\%$ \\
\hline \multicolumn{3}{|l|}{ Marital Status: } \\
\hline Married & 311 & 65.8 \\
\hline Singles & 123 & 26.0 \\
\hline Divorced/Separated & 4 & 0.8 \\
\hline Widowed & 35 & 7.4 \\
\hline \multicolumn{3}{|l|}{ Religion: } \\
\hline Islam & 179 & 37.8 \\
\hline Christianity & 287 & 60.7 \\
\hline Traditionalist & 4 & 0.8 \\
\hline Other Religion & 3 & 0.7 \\
\hline \multicolumn{3}{|l|}{ Ethnic: } \\
\hline Yoruba & 387 & 81.8 \\
\hline Hausa & 34 & 7.2 \\
\hline Igbo & 29 & 6.1 \\
\hline Other Ethnics & 23 & 4.9 \\
\hline \multicolumn{3}{|l|}{ Education Level: } \\
\hline Postgraduate & 54 & 11.4 \\
\hline First Degree & 186 & 39.4 \\
\hline $\mathrm{ND} / \mathrm{NCE}$ & 210 & 44.3 \\
\hline WAEC/GCE 'O’ Level & 23 & 4.9 \\
\hline
\end{tabular}

\section{MEASURES}

Structured questionnaires were used as instruments to collect data in the study. This questionnaire was designed into four sections. All scales used have 5-point Likert response format ranging from strongly disagree (scored 1) to strongly agree (scored 5). First section included demographic characteristics of electorates such as sex, marital status, religion, ethnicity, highest education qualification, and local government area. Second section included a 12-item godfatherism scale developed by the researcher for the study. High scores reflect greater perception of godfatherism. The researchers reported a reliability Cronbach alpha of 0.90. Third section included a 6-item modified Political Awareness scale extracted from the 44item Civic Attitudes and Skills Questionnaires (CASQ) that was originally developed by Moely, Mercer, Ilustre, Miron and McFarland (2002) based on awareness of local and national current events and political issues. High score indicates higher level of political awareness. The original developers reported internal consistency of 0.80 . In the current study, the researcher reported Cronbach alpha of 0.87 . Fourth section consisted of 6-item modified Voting behaviour scale extracted from the 44-item CASQ that was originally developed by Moely, Mercer, Ilustre, Miron and McFarland (2002). High score indicates higher voting behaviour. The original developer of the scale reported internal consistency alpha of 0.86 . In the present study a Cronbach alpha of 0.90 was reported by the researcher.

\section{Procedure for developing Perceived Godfatherism scale}

To start with, a group of 20 male and female electorates in Oyo state, Nigeria were approached and asked an open question each; that they should state what they think is godfatherism in the context of Nigerian politics. This exercise generated 22 items and those ones that appeared repeatedly were discarded. These items were given to five experts in political discussion which included lecturers in political science department and political analysts for them to identify those items that truly measure godfatherism in Nigerian context. This was found necessary in order to ensure face and content validity. At this stage the researcher was able to identify a potential set of items for the construct under consideration. The next step was the 
administration of these items to examine how well they confirmed expectations about the structure of the measure. This process includes an assessment of the psychometric properties of the scale and followed by an examination of its relationship with other variables of interest.

\section{Procedure}

Participation in filling the questionnaires was made voluntary. The researcher met with the electorates at various venues of their meeting places and made known the research purpose to them before they agreed to fill the questionnaires. Each respondent was thanked after filling in the questionnaire. Administration of questionnaires took five weeks. The researcher along with five trained research assistants distributed 500 questionnaires and 473 were returned representing $94.5 \%$ returned rate.

\section{RESULTS}

In order to investigate if ethnicity, religion, godfatherism and political awareness would predict voting behaviours among electorates, multiple regressions analysis was used. The result is presented in Table 2 .

Table 2: Multiple regression analysis showing independent and joint prediction of voting behaviour by ethnicity, religion, godfatherism and political awareness

\begin{tabular}{llllllll}
\hline Predictor Variables & $\mathbf{B}$ & $\mathbf{t}$ & $\mathbf{P}$ & $\mathbf{R}$ & $\mathbf{R}^{2}$ & $\mathbf{F}$ & $\mathbf{P}$ \\
Ethnicity & -.02 & -0.61 & $>.05$ & 0.53 & 0.29 & 46.50 & $<.05$ \\
Religion & -.02 & -0.50 & $>.05$ & & & & \\
Godfatherism & .17 & 3.55 & $<.05$ & & & & \\
Political Awareness & .41 & 8.77 & $<.05$ & & & & \\
\hline
\end{tabular}

The results presented in Table 2 showed that ethnicity and religion did not significantly independently predict voting behaviour among electorates $(\beta=-0.02 ; t=-0.61 ; p>.05 \& \beta=-$ $0.02 ; \mathrm{t}=-0.50 ; \mathrm{p}>.05$ ) respectively. This suggests that ethnicity and religion did not have independent direct relationships with voting behaviours of the electorates. However, godfatherism and political awareness independently predicted voting behaviours among electorates $(\beta=0.17 ; t=3.55 ; p<.05 ; \beta=0.41 ; t=8.77 ; p<.05)$ respectively. The result indicates that perceived godfatherism and political awareness have direct independent relationships with voting behaviours among electorates. In other words, the higher the perception of godfatherism, the higher the voting behaviour. In same vein, the result indicates that the higher political awareness by the electorates, the higher the levels of their voting behaviours. The result also revealed that all the predictor variables jointly predicted voting behaviours among electorates $\mathrm{F}(4,462)=46.50 ; \mathrm{p}<.05$, with $\mathrm{R}=0.53$; and $\mathrm{R} 2=0.29$. This result suggests that all the variables jointly accounted for $29 \%$ variation in voting behaviour of the electorates.

In determining the gender difference in voting behaviours of electorates, t-test for independent samples was used. The result is presented in Table 3.

Table 3: t-test showing gender difference in voting behaviour among electorates

\begin{tabular}{llllllll}
\hline & Gender & N & Mean & SD & df & t & P \\
Voting Behaviour & Male & 244 & 24.01 & 5.49 & 466 & -0.37 &.$>.05$ \\
& Female & 224 & 24.20 & 5.44 & & & \\
\hline
\end{tabular}


The result in Table 3 showed that gender did not have significant influence on voting behaviour among electorates $(t=-0.37 ; \mathrm{df}=466 ; \mathrm{p}>.05)$. The result further confirmed in the means where male electorates $(=24.01$ ) were not significantly difference in voting behaviour from female electorates $(=24.20)$. It suggests that there is no gender difference in voting behaviour among the electorates.

\section{DISCUSSION}

The study investigated ethnicity, religion, godfatherism and political awareness as predictors of voting behaviour among electorates in Oyo state, Nigeria. The results from the present study revealed that ethnicity, religion, perceived godfatherism and political awareness have combined contribution in explaining voting behaviour of electorates in southwestern, Nigeria. Specifically, the finding showed that all the predictor variables jointly predicted voting behaviour, but only perceived godfatherism and political awareness independently have direct relationships with voting behaviours of the electorates. In other words, ethnicity and religion as demographics and perceived godfatherism and political awareness as psychological variables have combined moderate levels of effects in explaining extent of vaoting behaviour among electorates in southwestern Nigeria. The current finding supports Balogun and Olapegba's (2007) reports that psychological and demographic variables jointly predicted voting behaviours among electorates within Ibadan metropolis. Similarly, the finding is in line with Oluwatula and Arogundade (2009) that some psychosocial correlates were found prominent in predicting the voting behaviour of Nigerians.

Ethnicity was found not to have a direct relationship with voting behaviour among electorates. This finding does not support Kelly (1982), who had indicated that ethnicity has an appreciable influence on electoral behaviours. Let us take a look at the Nigeria context; the finding suggests that voting behaviours of electorates is not the function of whether electorates are Yorubas, Hausas, Igbos or other ethnic groups in the country. Going by this finding in explaining voting behaviours of Nigerians in 1999, in some quarters, it largely believed that more of Hausas voted for the former president Olusegun Obasanjo; who happened to be a Yoruba in his first tenure in 1999. The finding is not also in line with Branton's (2004) assertion that "the relationship between individual-level voting and diversity is consistently negative, which is in line with the expectations regarding the relationship between diversity and white voting on racially tinged ballot initiatives." Ethnicity in Nigeria has however been found here that it does not affect voting behaviour of some selected southwestern Nigerians.

Religion was also found not to have direct relationship with voting behaviour among electorates. What this finding infers is that level at which electorates cast their votes is not determined whether they are of Islam or Christianity religious affiliation. The finding supports Brooks and Manza's (1997) emphasis that religion has a larger effect on voting than any other factor such as class. However, contrary to the present finding, this may be explained from the conclusion of Forster (2008) that the increased importance of foreign policy in presidential elections resulted in a decline in the influence of religion and religiously-based social preferences on voting behaviour at the national level. Irrespective of religion of electorates in Nigeria, current study has revealed that it does not affect voting behaviour.

Furthermore, the finding showed that perceived godfatherism had direct relationship with voting behaviours of electorates. There is no doubt that it is becoming glaring day-by-day that issue of godfatherism appears to be a strong factor in the political system of Nigeria. The current finding supports Adeoye (2009), who explored the relationship between godfathers and godsons with a particular attention to its influence on the development of Nigeria's 
politics, and seeming demise of resourceful governance in the country. Adeoye (2009) recognized the inevitability of godfathers in Nigerian politics but there was the need for proper management of godfather/godson relationship. Also, the finding is in line with Olarinmoye's (2008) report that electoral corruption is further entrenched by the political and social existential demands of the godfather, which can only be met by further exercises in electoral corruption, though this time in favour of the godfathers themselves. People of Nigeria are beginning to be aware of the significant effect of godfatherism on governance of many states. If the issue of godfatherism is not genuinely addressed with all sincerity; it may affect the electoral processes in country and continue to bastardize governance in the country. That is why it is a clarion call to all Nigerians; especially those eligible to vote.

It was further revealed that political awareness directly predicted voting behaviour of electorates. This suggests that the more informed are the electorates, the higher their tendencies to cast their votes. The finding is in line with Amer (2009) who reported that political awareness is accounted for electorates' interest in politics and frequency of political discussion. Also, the finding supports Oluwatula and Arogundade (2008) who found that there are some strong relationships between levels of psychological and political awareness; and need for personal power and need for institutional power among the participants. What this suggests is that the more electorates are informed or aware of the political systems in Nigeria, the more they are likely to engage in voting behaviours. An electorate who knows when election is taken place is aware politically and may desire to participate by casting his or her voting on the day.

Examining gender difference in voting behaviours of electorates, it was found that there was no gender difference in electorates' voting behaviours. The finding contradicts Studlar, Mcallister and Hayes (1998) who examined male-female differences in voting behaviour and found that males engage in voting behaviour than females. The current finding that has found no gender difference in voting behaviour of Nigerian electorates indicates that both sexes are involved in voting. The finding indicates that women are now coming out to exercise their civic rights unlike in the past that less of women got involved in politics. When there are many women vying for leadership positions, there is a tendency for women to come out in a large number and rally round the women aspirants.

\section{CONCLUSION}

The present study investigated ethnicity, religion, perceived godfatherism and political awareness as predictors of voting behaviour among electorates. Findings of the present study have revealed that ethnicity, religion, godfatherism and political awareness play significant joint contribution in determining voting behaviours among electorates in Nigeria. The findings further showed direct relationships between godfatherism and political awareness with voting behaviour. It can be concluded that the electorates in Nigeria see the issue of godfatherism appears to go a long way in determining their civic rights. It can also be concluded that as electorates are more informed about the political process in their communities, they are more likely to come out en masse to cast their votes. The study has been able to reveal that Nigerian government that desire to sustain democracy should make the electoral system free from godfatherism and motivate people to be more aware of the political process in the country. Availability of this will ensure high levels of voting behaviour among electorates in Nigeria. 


\section{Implications of Major Findings and Recommendations}

The findings of the present findings have some practical implications for Nigerian government and Independent National Electoral Commission as an electoral body in Nigeria. For example, building an electoral system in such a way that electorates will see credibility in their voting; devoid of threat, intimidation or godfatherism will be necessary for higher voting behaviour among Nigerian electorates. Especially, the idea that you may be attacked if you do not vote for a particular part should be removed. With this, electorates will feel more secure and be able to go exhibit their civic responsibility very well. The findings also have implication that there should be more education at various media on political process in Nigeria. It is therefore recommended that government of the day should make the environment more conducive for different parties to educate the populace about election processes without being intimated by the ruling party; as entire worlds awaits the upcoming 2015 election in Nigeria.

\section{References}

Abdul-jelili, A. G. (2009). Godfatherism' and Nigeria's Fourth Republic: Violence and Political Insecurity in Ibadan. Peace \& Conflict Studies Programme, Institute of African Studies, University of Ibadan.

Adeoye, O. A. (2009). Godfatherism and the future of Nigerian democracy African Journal of Political Science and International Relations, 3 (6), 268-272.

Amer, M. (2009). Political Awareness and its Implications on Participatory Behaviour A Study of Naga Women Voters in Nagaland. Indian Journal of Gender Studies, 16 (3), 359-374.

Balogun, S. K. \& Olapegba, P. O. (2007). Majority Carry the Vote: Psycho-Demographic Influence on Voting Behaviour. Stud. Tribes Tribals, 5(1): 5-7.

Branton, R. P. (2004). Voting in initiative elections: Does the context of racial and ethnic diversity matter? State Politics and Policy Quarterly. 4(3), 294-317.

Brooks, C. \& Manza, J. (1997). The religious factor in U.S. Presidential election 1960-1992. American Journal of Sociology, 103(1), 38-81.

Converse, P.E. (2000) Assessing the Capacity of Mass Electorates, Annual Review of Political Science, 3, pp. 331353.

Fastnow, C. J. Grant, T. \& Rudolph, T. J. (1999). Holy roll calls: Religious tradition and voting behaviour in the U.S. House. Social Science Quarterly. 80(4), 687- 701.

Forster, A. D. (2008) "Religion and Voting Behaviour in Contemporary U.S. Elections" Paper presented at the annual meeting of the Southern Political Science Association, Hotel Intercontinental, New Orleans, LA.

Fox, S. W. \& Richardson, J. T. (2001). Religion and voting on abortion reform: A follow-up study. Journal for the Scientific Study of Religion, 14(2), 159-164.

Gill, S. (2003). Gender and Voting Preferences in Japanese Lower House Elections. Japanese Journal of Political Science, $4: 1: 1-39$

Hobolt, S. (2005)."Deciding on Europe: Voting Behaviour in EU Referendums" Paper presented at the annual meeting of the American Political Science Association, Hilton Chicago and the Palmer House Hilton, Chicago, IL, Sep 02, 2004

Kelly, J. (1982). Class, ethnicity, and voting behaviour in Australia. Australian Journal of Political Science, 17 (2) 96 $-107$

Mamah, E (2007). 'First Generation Politician Started Godfatherism', August 27, 2004.

Moely, B. E., Mercer, S. H., Ilustre, V., Miron, D., \& McFarland, M. (2002). Psychometric properties and correlates of the Civic Attitudes and Skills Questionnaire (CASQ): A measure of students' attitudes related to service-learning. Michigan Journal of Community Service-learning, 8(2), 15-26.

Olarinmoye, O. O. (2008). Godfathers, political parties and electoral corruption in Nigeria. African Journal of Political Science and International Relations, 2(4), pp. 066-073. 
Oluwatula, O. \& Arogundade, O. (2009). "Psychosocial Correlates as Predictors of Voting Behaviour in Nigeria" Paper presented at the annual meeting of the International Society of Political Psychology, Classical Chinese Garden, Portland, Oregon USA, Jul 04, 2007

Oluwatula, O. O. \& Arogundade, O. T. (2008) "Psycho-Political Awareness and Desire for Political Power" Paper presented at the annual meeting of the ISPP 31st Annual Scientific Meeting, Sciences Po, Paris, France.

Sanbonmatsu, K. (2002). Gender stereotypes and vote choice. American Journal of Political Science. 46(1), 20-34.

Studlar, D. T., Mcallister, I. \& Hayes, B. C. (1998). Explaining the gender gap in voting: A cross-national analysis. Social science quarterly. vol. 79, no4, pp. 779-798 (2 p.) 